\title{
HIGH-PERFORMANCE LIQUID CHROMATOGRAPHY FOR DETERMINATION OF AROMATIC ALDEHYDES IN WINE DISTILLATES
}

\author{
Elena Nezalzova \\ Scientific-Practical Institute of Horticulture and Food Technologies \\ 59, Vierul str., Chisinau, Moldova, e-mail: lena_nezalzova@yahoo.com
}

\begin{abstract}
Quality control of alcoholic beverages, coming into the market, is a defining element in preventing the production and supplying of defective products. One of the main criteria for quality control of wine distillates is to estimate their age, and more precisely the period of maturation as the dominant factor in determining the quality of cognacs and, consequently, their market price. On the opinion of majority scientists, one of the main factors, which determines the age of wine distillates, is the content of aromatic aldehydes, mostly vanillin, and their ratio.
\end{abstract}

Keywords: wine distillate, age of maturation, aromatic aldehydes, high-performance liquid chromatography.

\section{Introduction}

Extraction of natural phenolic compounds from oak wood by wine distillate and their hydrolysis in the process of aging leads to the formation of aromatic alcohols and their subsequent oxidation to aromatic aldehydes. Aromatic aldehydes (vanillin, siringic, sinapic, coniferylic, p-oxybenzoic aldehydes etc.) by their organoleptic properties are involved in formation of cognac's flavor and aroma. In addition, according to many researchers, the concentration of aromatic aldehydes can serve as a marker of duration of the wine distillate's maturation in oak barrels. In this regard, relevant is the correct quantification of aromatic aldehydes in the aged wine distillates, from which subsequently are made cognacs.

From aromatic aldehydes in wine distillates are found mostly compounds of guaiacyl (I) and siringyl (II) series (Table 1) $[2,4]$.<smiles>[R]Cc1cc([2H])cc([R])c1[R]</smiles>

Vanillin: $\mathrm{R}_{1}=\mathrm{H} ; \mathrm{R}_{2}=\mathrm{OH} ; \mathrm{R}_{3}=\mathrm{OCH}_{3}$ Siringic aldehyde: $\mathrm{R}_{1}=\mathrm{R}_{3}=\mathrm{OCH}_{3} ; \mathrm{R}_{2}=\mathrm{OH}$ p-oxybenzoic aldehyde: $\mathrm{R}_{1}=\mathrm{R}_{3}=\mathrm{H} ; \mathrm{R}_{2}=\mathrm{OH}$

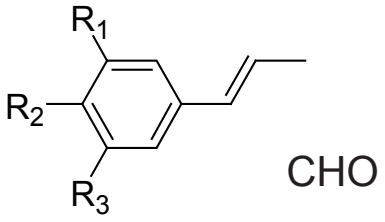

Coniferylic aldehyde: $\mathrm{R}_{1}=\mathrm{H} ; \mathrm{R}_{2}=\mathrm{OH} ; \mathrm{R}_{3}=\mathrm{OCH}_{3}$ Sinapic aldehyde: $\mathrm{R}_{1}=\mathrm{R}_{3}=\mathrm{OCH}_{3} ; \mathrm{R}_{2}=\mathrm{OH}$

I

Aromatic aldehydes give characteristic color reactions with various reagents. A number of spectral methods of their quantitative determination is based on this property. However, according to I. Skurikhin, vanillin, siringic and sinapic aldehydes in the ultraviolet absorption spectrum have similar maxima. As a result, the spectrophotometric method can show the total content of these components. Therefore, rather contradictory data on the content of individual aromatic aldehydes in wine distillates and cognacs often appear. It concerns mostly vanillin.

In the present, in the existing regulatory-technical documentation for production of cognacs (SM 145:2003 "Divinuri. Condiții tehnice"), for ageing proof of wine distillates the concentration of an aromatic aldehyde - vanillin is used. But spectrophotometric determination method of analysis is provided for this purpose. 
Table 1

\begin{tabular}{|l|c|c|c|}
\hline \multirow{2}{*}{ Aromatic aldehydes } & The content of aromatic aldehydes in wine & \multicolumn{2}{|c|}{ Threshold concentrations, mg/l } \\
\cline { 3 - 4 } & distillates of 1-15 years old, mg/l & Aroma & Taste \\
\hline Vanillin & $0,1-1,6$ & 0,01 & 0,1 \\
Siringic aldehyde & $0,2-2,8$ & 50 & 100 \\
Sinapic aldehyde & $0,5-2,4$ & 200 & 200 \\
Coniferylic aldehyde & $0,9-2,6$ & 3 & 10 \\
Total & $1,9-8,7$ & & \\
\hline
\end{tabular}

I. Skurikhin and others have found that the content of aromatic aldehydes in the process of aging of wine distillates in contact with oak is growing. The relation between simple aromatic aldehydes (vanillin and siringic aldehyde) and aldehydes with the double bond (sinapic and coniferylic aldehydes) is changed ambiguously in the process of aging, so using only vanillin for characterization the degree of wine distillate's maturation without regarding other aromatic aldehydes represents a wrong approach.

The method of high-performance liquid chromatography (HPLC) allows us to identify and quantify the individual aromatic aldehydes from the general group of these compounds, selected by optical methods.

\section{Materials and methods}

Spectrophotometric method of SM 145:2003 is based on measuring the optical density of alkaline solution of vanillin in the ultraviolet part of the spectrum at $\lambda=350 \mathrm{~nm}$.

The method of high-performance liquid chromatography (HPLC) allows to separate the phenolic compounds and the products of their degradation - aromatic aldehydes and acids extracted by wine distillate from oak wood, on a special chromatographic column, and then to determine them quantitatively. We picked the best mode of separating a mixture of aromatic aldehydes and their predecessors - the aromatic acids and used a method developed for quantitative differential determination of the above mentioned compounds, including vanillin, in wine distillates of different periods of maturation.

For our research we selected about 30 samples of wine distillates of different periods of maturation (young, from 2 to 27 years old), prepared at domestic enterprises and imported into Republic of Moldova.

Determination of aromatic aldehydes and acids by HPLC was performed on the liquid chromatograph LC20A Prominence, Shimadzu, on the column CC 125/4 Nucleosil 100-5C18 Nautilus. Detector SPD-20AV UV/VIS, by which is equipped this liquid chromatograph, includes deuterium and tungsten halogen lamps, as a result the analytical capabilities are expanded to the visible range. As an eluent we used a mixture of methanol and acetic acid. Separation of standard mixture of aromatic aldehydes was carried out under the following conditions:

The volume of injected sample, $\mu \mathrm{l}$

Wavelength, nm

280

Eluent

Solution A - Methanol. Solution B - 0,5\% Acetic acid

Gradient program:

Start $\quad-5 \%$ solution A, - 95\% solution B

10 min $\quad-15 \%$ solution A, - $85 \%$ solution B

$45 \mathrm{~min} \quad-40 \%$ solution A, - $60 \%$ solution B

55 min $-92 \%$ solution A, $-2 \%$ solution B

Stop $\quad-5 \%$ solution A, $-95 \%$ solution B

The rate of the eluent, $\mathrm{ml} / \mathrm{min}$

0,8

Duration of analysis, min

60

The content of vanillin was determined on the spectrophotometer CФ-46 by the method indicated in SM 145:2003.

\section{Results and discussion}

Figure 1 shows the chromatogram of a standard mixture solution of aromatic aldehydes and acids, on which there is good separation of the peaks and sensitivity. 


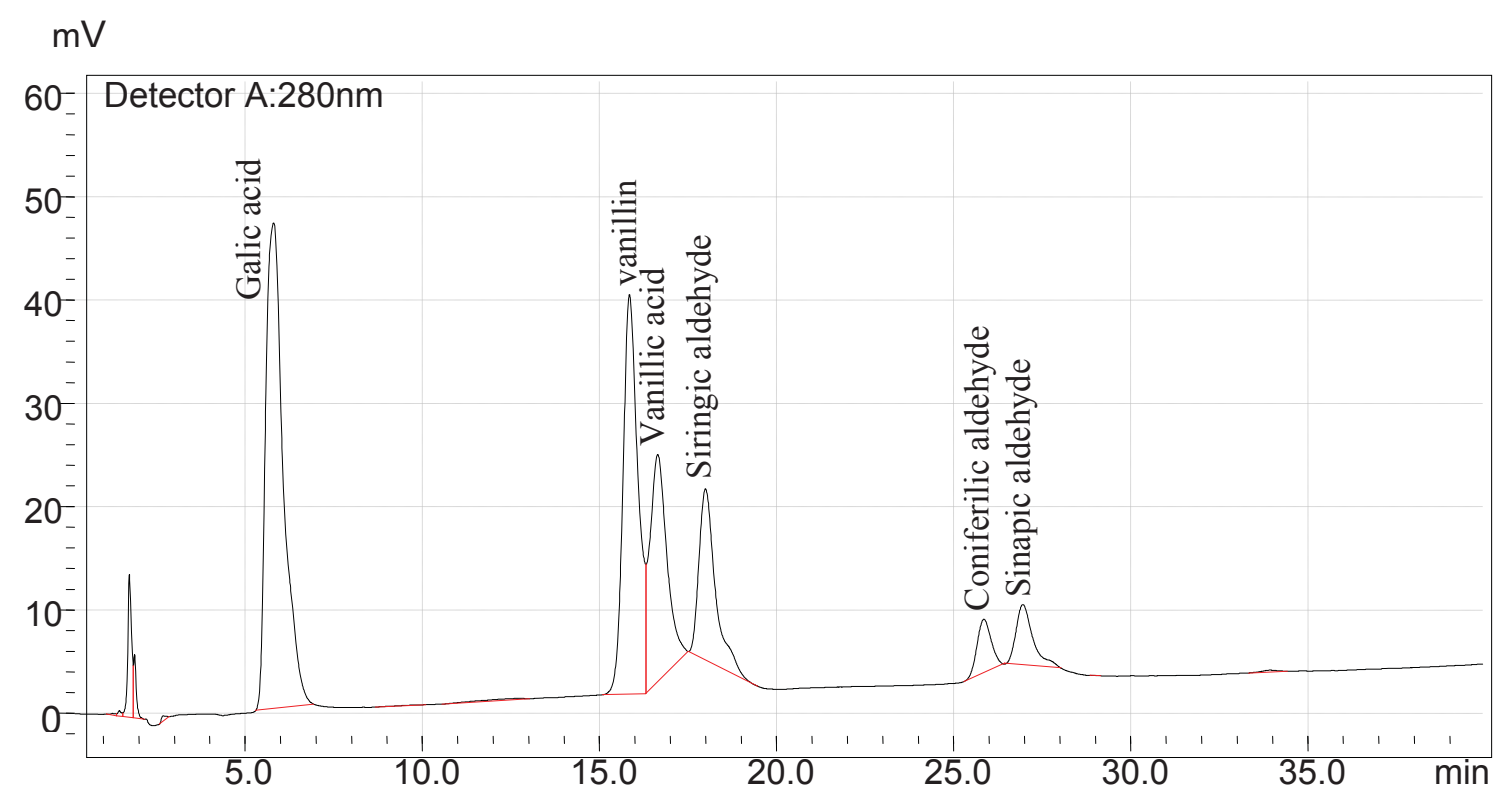

Fig. 1. Chromatogram of standard mixture solution of aromatic aldehydes and acids.

We separated by HPLC method the mixture of aromatic aldehydes and natural sample of the aged wine distillate in the measurement mode of two wavelengths 280 and $254 \mathrm{~nm}$. Figures 2 and 3 show the chromatograms, on which it is seen that the analysis in this mode allows in one step to get a good separation of the peaks of studied substances. Thus, the established modes of analysis by HPLC can differentially determine the concentration of individual aromatic aldehyde and the corresponding aromatic acids in wine distillates.

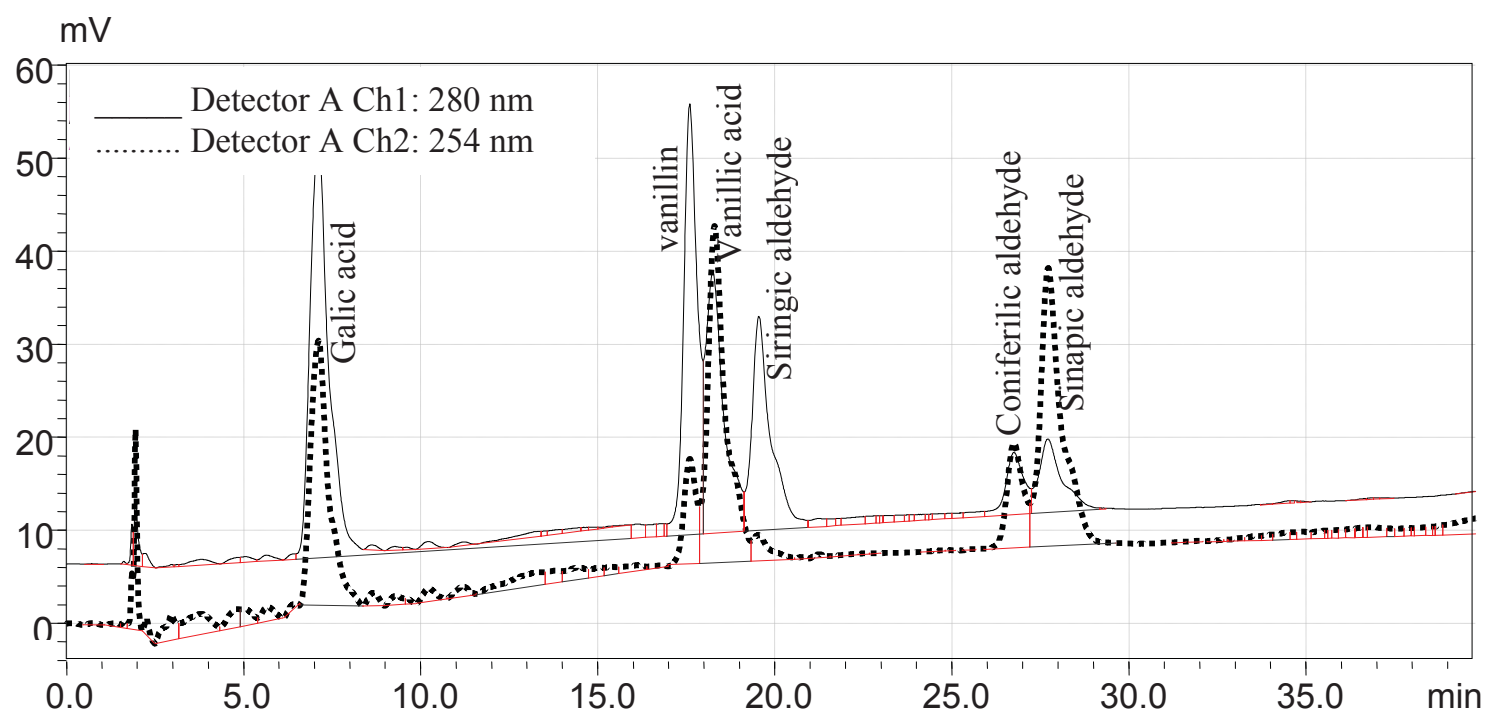

Fig. 2. Chromatogram of standard mixture solution of aromatic aldehydes and acids on two wavelengths: 280 and $254 \mathrm{~nm}$. 


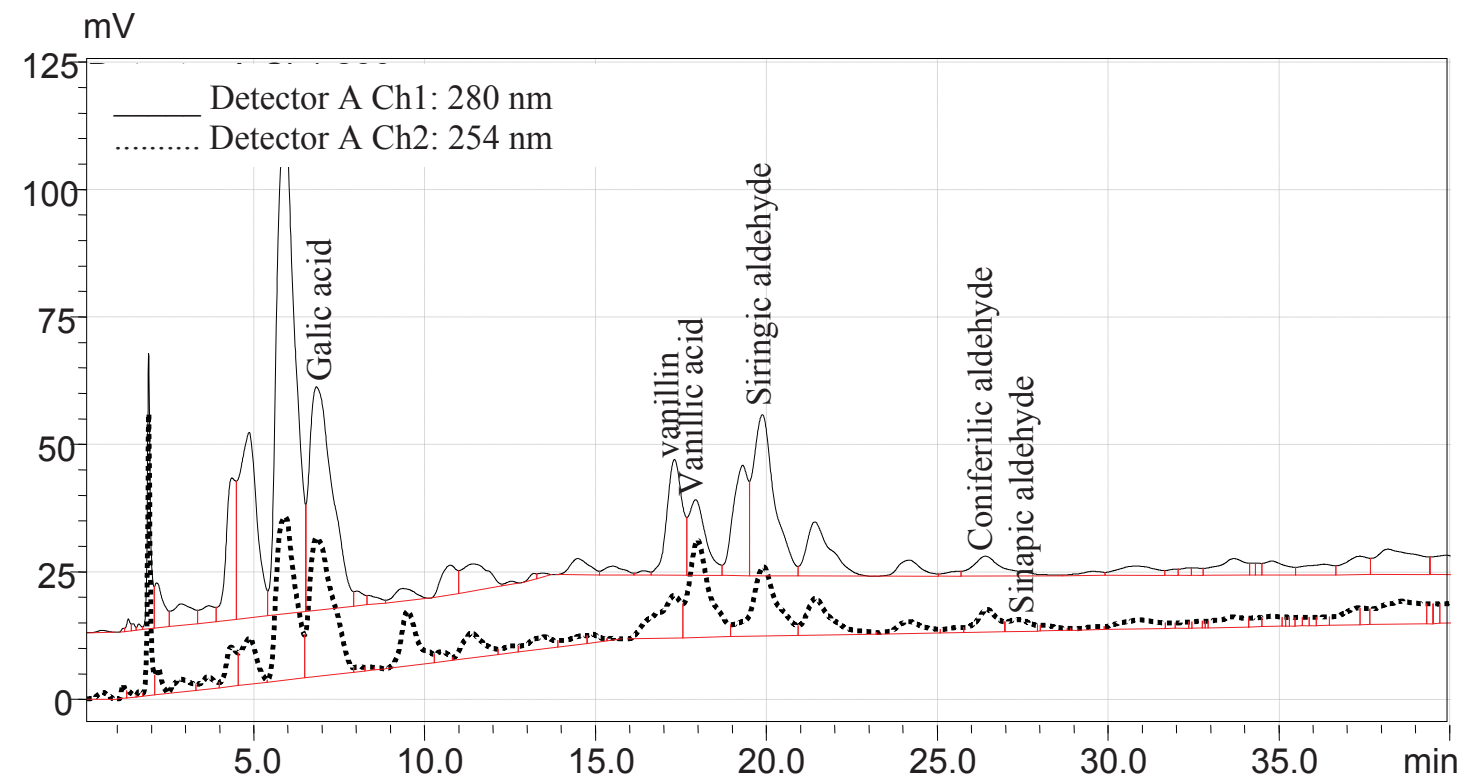

Fig. 3. Chromatogram of composition of aromatic aldehydes and acids of natural sample of the aged wine distillate, year 1980, on two wavelengths: 280 and $254 \mathrm{~nm}$.

We have carried out studies on the comparison of results obtained in determining the content of vanillin in wine distillate of different periods of maturation by the spectrophotometric method in SM 145:2003 "Divinuri. Condiții tehnice" and by high-performance liquid chromatography (HPLC).

We have seen that they differ (Table 2). The content of vanillin, determined by HPLC, was significantly lower than the one, established by spectrophotometric method.

In the current SM 145:2003 "Divinuri. Condiții tehnice" for characterization the physico-chemical composition of aged wine distillates the amount of vanillin is only used, and in wine distillates up to 5 years old this parameter is not normalized, and in the distillate over 6 years old the content of vanillin may not exceed $16 \mathrm{mg} / \mathrm{dm}^{3} / 4 /$. Our studies show that this parameter does not reflect the real picture, the amount of accumulated vanillin is significantly lower than the indicated value.

The content of vanillin in aged wine distillates, determined by different methods

\begin{tabular}{|c|c|c|}
\hline \multirow{2}{*}{ The year of laying for maturation } & \multicolumn{2}{|c|}{ The content of vanillin, mg/dm } \\
\cline { 2 - 3 } & $\begin{array}{c}|c| \\
\text { Spectrophotometric } \\
\text { method on SM145:2003 }\end{array}$ & $\begin{array}{c}\text { High-performance liquid chromatography } \\
\text { (HPLC) }\end{array}$ \\
\hline 1983 & 13,0 & 5,6 \\
\hline 1985 & 17,7 & 6,1 \\
\hline 1988 & 13,5 & 6,6 \\
\hline 1989 & 14,0 & 6,6 \\
\hline 2003 & 12,7 & 7,9 \\
\hline 2004 & 8,5 & 5,2 \\
\hline 2005 & 6,2 & 2,7 \\
\hline 2005 & 5,0 & 3,2 \\
\hline 2005 & 9,5 & 5,5 \\
\hline 2007 & 2,7 & 1,2 \\
\hline 2007 & 2,0 & 0,5 \\
\hline 2008 & 1,2 & 0,4 \\
\hline & & \\
\hline & & \\
\hline & & \\
\hline
\end{tabular}




\section{Conclusion}

The method of determination of aromatic aldehydes in wine distillates by high-performance liquid chromatography has been elaborated. Application of high-performance liquid chromatography (HPLC) allows to eliminate errors at the control of the content of aromatic aldehydes, especially vanillin, in maturated wine distillates.

\section{Acknowledgements}

This work was carried out under the direction of Academician Boris Gaina.

Consultant - Elena Scorbanov.

\section{References}

[1]. Власов В.Н., Маруженков Д.С. Анализ качества бренди из винограда методом хроматомасспектрометрии, В: Виноград и вино России, 1999, № 1, с.28-31

[2]. Кишковский 3.Н., Скурихин И.М. Химия вина. - Москва: Пищевая промышленность, 1976

[3]. Савчук С.А., Колесов Г.М. Хроматографические методы контроля качества коньяков и коньячных спиртов, В: Аналитическая химия, 2005, №8, с.848-868

[4]. Скурихин И.М. Химия коньяка и бренди Москва: Де Ли Принт, 2005.296 с.

[5]. SM 145:2003”Divin.Condiții tehnice"

[6]. Незальзова Е.Н., Скорбанова Е.А., Гаина Б.С.и др. Выявление объективных показателей возраста коньяков оптическими методами исследования. В: Сборник научных трудов VII международной научной конференции “Лазерная физика и оптические технологии”, Минск, 2008, часть II, с. 215-218. 